\title{
Ovarian Response and Hormonal Profiles in Heifers After Immunization and Re-immunization Against Inhibin $\alpha$-Subunit
}

\author{
Satoshi AKAGI ${ }^{1)}$, FangXiong $\mathrm{SHI}^{2,3,4)}$, Hiroyuki KANEKO ${ }^{5)}$, Gen WATANABE ${ }^{2,3)}$, \\ Con G. TSONIS ${ }^{6}$ and Kazuyoshi TAYA ${ }^{2,3)}$
}

1) Reproductive Cell Biology Laboratory, Department of Animal Breeding and Reproduction,
National Institute of Livestock and Grassland Science, Ibaraki 305-0901,
${ }^{2)}$ Department of Basic Veterinary Sciences, The United Graduate School of Veterinary
Sciences, Gifu University, Gifu 501-1193, ${ }^{3)}$ Laboratory of Veterinary Physiology, Tokyo
University of Agriculture and Technology, Tokyo 183-8509, Japan, ${ }^{4)}$ College of Animal
Sciences, Zhejiang University, Hangzhou 310029, China, ${ }^{5)}$ Genetic Diversity Department,
National Institute of Agrobiological Sciences, Ibaraki 305-8602, Japan and
${ }^{6)}$ Biotech Australia Pty Ltd, PO Box 20, East Roseville, NSW 2460, Australia

\begin{abstract}
To explore a strategy for superovulation in heifers, effects of immunization and reimmunization of Japanese beef heifers against inhibin on ovarian response and hormonal profiles were investigated. On day 9 of the estrous cycle (day $0=$ day of estrus), ten heifers were primary injected intramuscularly (i.m.) either with inhibin vaccine (recombinant ovine inhibin $\alpha$-subunit in oil emulsion, $125 \mu \mathrm{g} / \mathrm{ml}$ ) or a placebo (Montanide:Marcol adjutant alone) followed by two booster injections at one estrous cycle intervals (immunized group). One year later, 3 injections of inhibin vaccine were given the same as in the first year (re-immunized group). Inhibin antibody titers in plasma of immunized heifers increased after the second injection of inhibin vaccine and in 3 out of 5 immunized heifers and multiple-ovulation $(2.4 \pm 0.6, n=5)$ was induced after the third injection. On the other hand, in the re-immunized heifers, the plasma inhibin antibody titers increased sharply after the first injection of inhibin vaccine and in 4 out of 5 re-immunized heifers multiple ovulation $(4.4 \pm$ $1.1, \mathrm{n}=5$ ) was induced after the first injection of inhibin vaccine. In all re-immunized heifers multipleovulation was induced after the third injection of inhibin vaccine $(5.0 \pm 1.1, \mathrm{n}=5)$. The results also showed that the ovulation rates were positively correlated to circulating inhibin antibody titers and plasma levels of FSH. These results confirmed that active immunization against inhibin $\alpha$-subunit induced multiple ovulation mainly by attenuation of the suppressive effect of inhibin on FSH secretion in heifers and indicated that re-immunization against inhibin was a good way to induce multiple-ovulation in cattle.
\end{abstract}

Key words: Heifer, Active immunization, Inhibin, Superovulation, Cattle

(J. Reprod. Dev. 48: 599-605, 2002)

$t$ is reported that immunoneutralization of inhibin to induce superovulation provides an alternative to current follicle stimulating hormone

Accepted for publication: August 20, 2002

Correspondence: K. Taya
(FSH) or equine chorionic gonadotropin (eCG) treatment protocols for the production of transferable embryos in mammals [1-8]. Several studies have shown that active immunization of heifers against inhibin $\alpha$-subunit [9-13] and passive 
immunization of cows against inhibin [5] increased ovulation rates, which is generally considered to be a result of neutralization of the suppressive effect of inhibin on the secretion of FSH, but the response of inhibin-immunized cattle varied greatly and was unpredictable. Therefore, further studies are needed to investigate how active immunization against the inhibin $\alpha$-subunit can consistently sustain optimal levels of inhibin antibody titer for with consistency in cattle. On the other hand, although ultrasonographic examination has revealed that follicular development occurs in two or three waves related to FSH profiles during the normal estrous cycle [14-16], the relationships between follicular dynamics in each wave of follicular growth and FSH profiles after active immunization against inhibin have not been fully documented.

In the present study we therefore investigated the changes in plasma concentrations of FSH and follicular dynamics and ovulation rates in Japanese beef cattle after active immunization and reimmunization against the inhibin $\alpha$-subunit, and tried to find a good way to induce superovulation in cattle.

\section{Materials and Methods}

\section{Experimental design}

Eight Japanese black heifers and two Japanese brown heifers between 5 and 9 years of age and weighing $455-510 \mathrm{~kg}$, clinically normal with a regular estrous cycle and non pregnant, were used. They were randomly divided into immunized and control groups. On day 9 of the estrous cycle (day 0 = day of estrus), the heifers were injected intramuscularly (i.m.) either with inhibin vaccine (recombinant ovine inhibin $\alpha$-subunit in oil emulsion, $125 \mu \mathrm{g} / \mathrm{ml}$ ) or a placebo (Montanide:Marcol adjutant only) followed by two booster injections at estrous cycle length intervals. One year later, 3 injections of vaccine were given, as in the first year. All the heifers received a single i.m. injection of prostaglandin $\mathrm{F}_{2 \alpha}$ analogue (PG; Estrumate, Sumitomo Pharm., Osaka, Japan) on day 18 of the estrous cycle after the 3rd injection. The number of different sized follicles and corpora lutea were examined by ultrasonography. To examine the plasma inhibin antibody titers, blood samples were collected via venipuncture on day 9 (immediately before immunogen injection) and on day 18 of three consecutive estrous cycles after primary injections.To study hormone profiles, blood samples were collected every $12 \mathrm{~h}$ just after the 2 nd booster and stored at $-40 \mathrm{C}$ until plasma concentrations of FSH, luteinizing hormone (LH), estradiol and progesterone were measured.

\section{Inhibin vaccine}

The $\alpha$-subunit of ovine inhibin produced in E. coli the by the recombinant DNA method [17] was used as an immunogen. Immunizations were given at a dose of $1 \mathrm{ml}$ of the immunogen $(125 \mu \mathrm{g} / \mathrm{ml})$ in Montanide 888:Marcol 52 (1:9) each time.

\section{Determination of ovarian response}

The populations of ovarian follicles in each group were examined at $24 \mathrm{~h}$ intervals from the day of the second booster by using an ultrasound scanner (SSD-650CL, Aloka, Tokyo, Japan) as described previously [18]. The ovulation rate was estimated by counting the number of corpora lutea by ultrasonography between 7 and 9 days after estrus. Follicles were arbitrarily divided into three groups according to their mean diameter (small; $\geq 4<7$, medium; $\geq 7<10$, large; $\geq 10 \mathrm{~mm}$ in diameter). In these Japanese beef cattle, follicles larger than 10 $\mathrm{mm}$ in diameter were considered to be preovulatory follicle in the normal estrous cycle [16].

\section{Radioimmunoassays (RIAs)}

Plasma concentrations of FSH were measured by RIA [19] with anti-bovine FSH $\beta$-subunit antiserum (UCB Bioproduct, S.A.Brainel'Alleud, Belgium), USDA-FSH-BP3 for radioiodination and USDAFSH-B1 as a reference standard. Plasma concentrations of LH were measured by RIA [20] with anti-ovine LH serum (YM\#18), USDA-bLH-I-1 for radioiodination and USDA-bLH-B-5 as a reference standard (YM\#18 was supplied by Dr. Y. Mori, The University of Tokyo, Japan and the other RIA materials for bovine FSH and LH were supplied by Dr. D. J. Bolt, USDA, Beltsville, MD, U.S.A.). The intra- and inter-assay coefficients of variation were $3.0 \%$ and $9.8 \%$ for $\mathrm{FSH}$ and $6.5 \%$ and $11.5 \%$ for $\mathrm{LH}$, respectively.

Plasma concentrations of estradiol and progesterone were determined as described previously [21] with antiserum to estradiol-17 $\beta$ (GDN244), and progesterone (GDN337) (supplied 
by Dr. G. D. Niswender, Animal Reproduction and Biotechnology Laboratory, Colorado State University, Fort Collins, CO, U.S.A.). In the assay for estradiol, substances that interfered with the estradiol assay were removed from plasma samples with a mixture of $2.0 \mathrm{ml} \mathrm{n}$-hexane and $0.5 \mathrm{ml}$ acetonitrile [22]. The intra- and inter-assay coefficients of variation were $4.2 \%$ and $9.8 \%$ for estradiol and $5.8 \%$ and $13.4 \%$ for progesterone, respectively. Plasma inhibin antibody titers were determined by measuring the binding of ${ }^{125} \mathrm{I}$ labeled inhibin at a final dilution of 1:12 as described previously [23].

\section{Statistics}

Results were subjected to analysis of variance for repeated measures [24]. When a significant effect was obtained with analysis of variance, the significance of the difference between two means was determined by Student's $t$-test. Calculation was carried out by the General Linear Model Procedure of the Statistical Analysis Systems [25]. A value of $\mathrm{P}<0.05$ was considered to be significant.

\section{Results}

Inhibin-binding activity in the circulation (Fig. 1)

In the first year experiment, inhibin antibody titers in the plasma of the immunized group increased gradually after the first booster, and reached a peak level at 9 days after the second booster (Fig. 1, a). In the second year experiment, inhibin antibody titers in plasma of the immunized group increased rapidly and reached a peak level after the first injection and remained at peak levels during the second and third injections (Fig. 1, b). On the other hand, the placebo injection had no effect on inhibin antibody titers in plasma during the two consecutive years.

\section{Ovarian response (Table 1 and Fig. 2)}

The mean number of follicles from the start of the follicular wave are shown in Fig.2. All heifers in the experiment had two waves of follicular development after the second booster injection except one control heifer which had only one preovulatory wave. The emergence and duration of follicle waves in immunized heifers were similar to those in control animals. In the preovulatory wave, the numbers of follicles of different size in

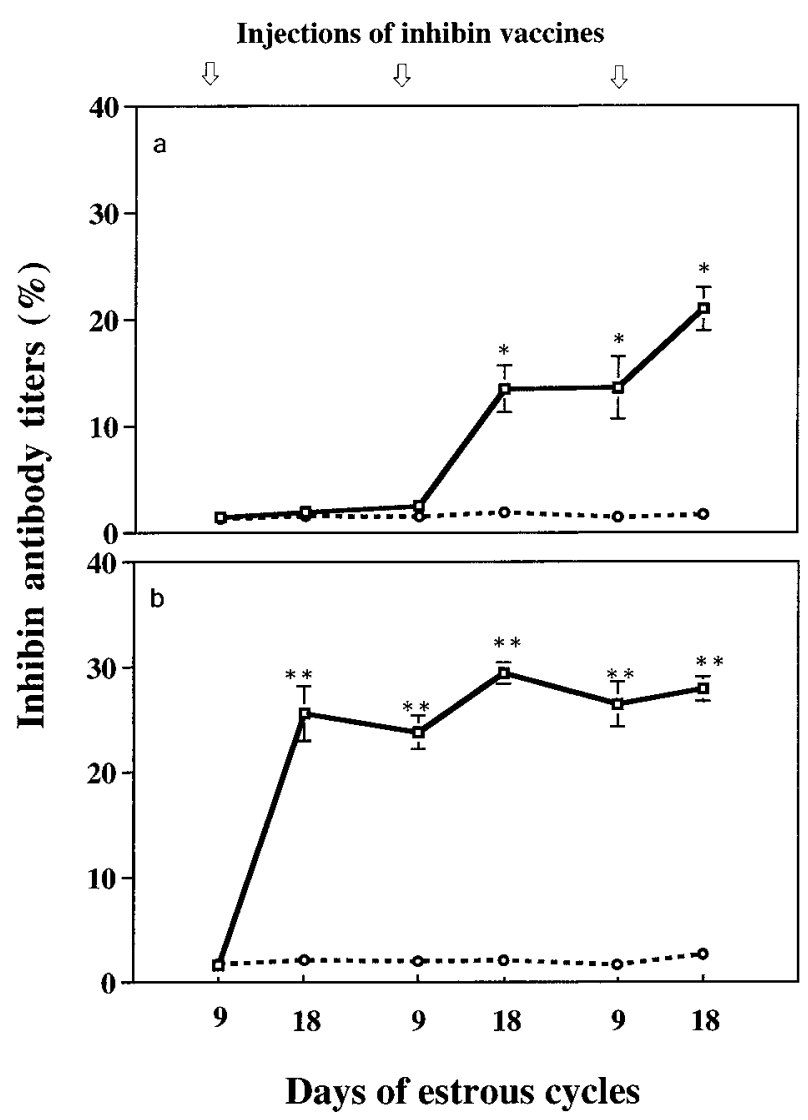

Fig. 1. Inhibin antibody titer in plasma of heifers after immunization (a) and re-immunization (b) against the inhibin $\alpha$-subunit. Note: (a) immunization in the first year, (b) re-immunization in the second year. Arrows represent injections of placebo $(O)$ or inhibin vaccine $(\square)$. Values are shown as the means \pm SEM in five observations. ${ }^{*} \mathrm{P}<0.05$ compared with the value for the respective control (Student's t-test).

immunized heifers were greater than those in control heifers. There were no significant differences between immunized and control groups in the maximum diameters of dominant follicles in each waves; they were $8.2 \pm 0.5 \mathrm{~mm}(\mathrm{n}=4$; control group) and $8.8 \pm 0.5 \mathrm{~mm}(\mathrm{n}=5$; immunized group) in the first wave after the second booster injection, and $11.8 \pm 0.3 \mathrm{~mm}(\mathrm{n}=5$; control group) and $11.3 \pm 0.5 \mathrm{~mm}(\mathrm{n}=5$; immunized group $)$ in the preovulatory wave, respectively.

In three out of five immunized heifers multiple ovulations were induced after the third booster injection in the first year experiment (Table 1). In the second year experiment, in 4 out of 5 heifers multiple ovulations were induced after the first injection. In all heifers multiple ovulations were 
Table 1. Ovulation rates in heifers after immunization and re-immunization against inhibin

\begin{tabular}{lccccccc}
\hline Group & \multicolumn{3}{c}{ Number } & \multicolumn{3}{c}{ Re-immunization } \\
\cline { 2 - 7 } & & 1st & 2nd & 3rd & 1st & 2nd & 3rd \\
\hline Treatment & A & 1 & 1 & 3 & 6 & 4 & 6 \\
& B & 1 & 1 & 4 & 7 & 1 & 8 \\
& C & 1 & 1 & 3 & 5 & 1 & 2 \\
& D & 1 & 1 & 1 & 3 & 5 & 6 \\
& E & 1 & 1 & 1 & 1 & 4 & 3 \\
\hline Control & Mean \pm SEM & 1 & 1 & $2.4 \pm 0.6$ & $4.4 \pm 1.1$ & $3.0 \pm 0.8$ & $5.0 \pm 1.1$ \\
& F & 1 & 1 & 1 & 1 & 1 & 1 \\
& G & 1 & 1 & 1 & 1 & 1 & 1 \\
& H & 1 & 1 & 1 & 1 & 1 & 1 \\
& I & 1 & 1 & 1 & 1 & 1 & 1 \\
& J & 1 & 1 & 1 & 1 & 1 & 1 \\
\hline & Mean & 1 & 1 & 1 & 1 & 1 & 1 \\
\hline
\end{tabular}

Numbers in the table are the numbers of corpora lutea in ovaries between day 7 and day 9 after each estrus.

successfully induced after the third injection in the re-immunized group. All heifers with multiple ovulations exhibited high levels (over $25 \%$ ) of plasma inhibin antibody titers. The numbers of antral follicles and ovulations were closely correlated with the inhibin antibody titers (follicles $\mathrm{r}=0.59, \mathrm{P}<0.05$; ovulation $\mathrm{r}=0.73, \mathrm{P}<0.01)$.

Plasma concentrations of FSH, LH, estradiol and progesterone (Fig. 3)

Mean plasma concentrations of FSH $(12.1 \pm 0.4$ $\mathrm{ng} / \mathrm{ml}, \mathrm{n}=5$ ) in the immunized group were significantly $(\mathrm{P}<0.01)$ higher during the 11-day (days 9-19 of the estrous cycle) period after the second booster injection than the values $(8.4 \pm 0.3$ $\mathrm{ng} / \mathrm{ml}, \mathrm{n}=5$ ) in the control group. Concentrations of plasma LH ranged from 0.3 to $0.7 \mathrm{ng} / \mathrm{ml}(\mathrm{n}=10)$ in both control and immunized groups and did not differ significantly from group to group (Fig. 3b). Mean FSH concentrations during the 11-day period after the second booster injection closely correlated with the incidence of multiple-ovulation $(r=0.83$, $\mathrm{P}<0.01$ ).

In the control animals, concentrations of plasma estradiol increased significantly $(\mathrm{P}<0.05) 12 \mathrm{~h}$ after PG injection (Fig. 3c). Immunization against inhibin $\alpha$-subunit produced a further increase in the plasma concentration of estradiol after PG injection compared to the control animals and the peak level in these animals was $18.4 \pm 3.2 \mathrm{pg} / \mathrm{ml}$ $(\mathrm{n}=5)$, significantly $(\mathrm{P}<0.05)$ higher than the control value $(9.4 \pm 0.7 \mathrm{pg} / \mathrm{ml}, \mathrm{n}=5)$.

Plasma concentrations of progesterone ranged from 4 to $7 \mathrm{ng} / \mathrm{ml}$ before PG injection and dropped sharply within $12 \mathrm{~h}$ after PG treatment, remaining low thereafter. Plasma concentrations of progesterone before PG injection in the immunized group tended to be higher than in the control group (Fig. 3d).

\section{Discussion}

The present study clearly demonstrated that reimmunization with only one injection of inhibin vaccine sharply produced peak levels of plasma inhibin antibody titer in immunized heifers, and three injections with inhibin vaccine successfully induced multiple ovulation in all immunized heifers. These results indicated that active immunization against inhibin $\alpha$-subunit is a longacting and efficient method to induce multiple ovulations in cattle.

In the first year experiment, active immunization against inhibin $\alpha$-subunit also significantly increased the number of follicles in the PG-induced preovulatory wave after the 2 nd booster and subsequently induced multiple ovulations. The number of ovulations and antral follicles were positively correlated to the circulating inhibin antibody titers, and these results were in agreement with recent reports [9, 26-30]. In the present study, ovulation rates were also positively correlated with plasma levels of FSH. Mean plasma concentrations of FSH in multiple ovulating heifers were significantly $(44 \%, \mathrm{P}<0.01)$ higher during the 11 - 


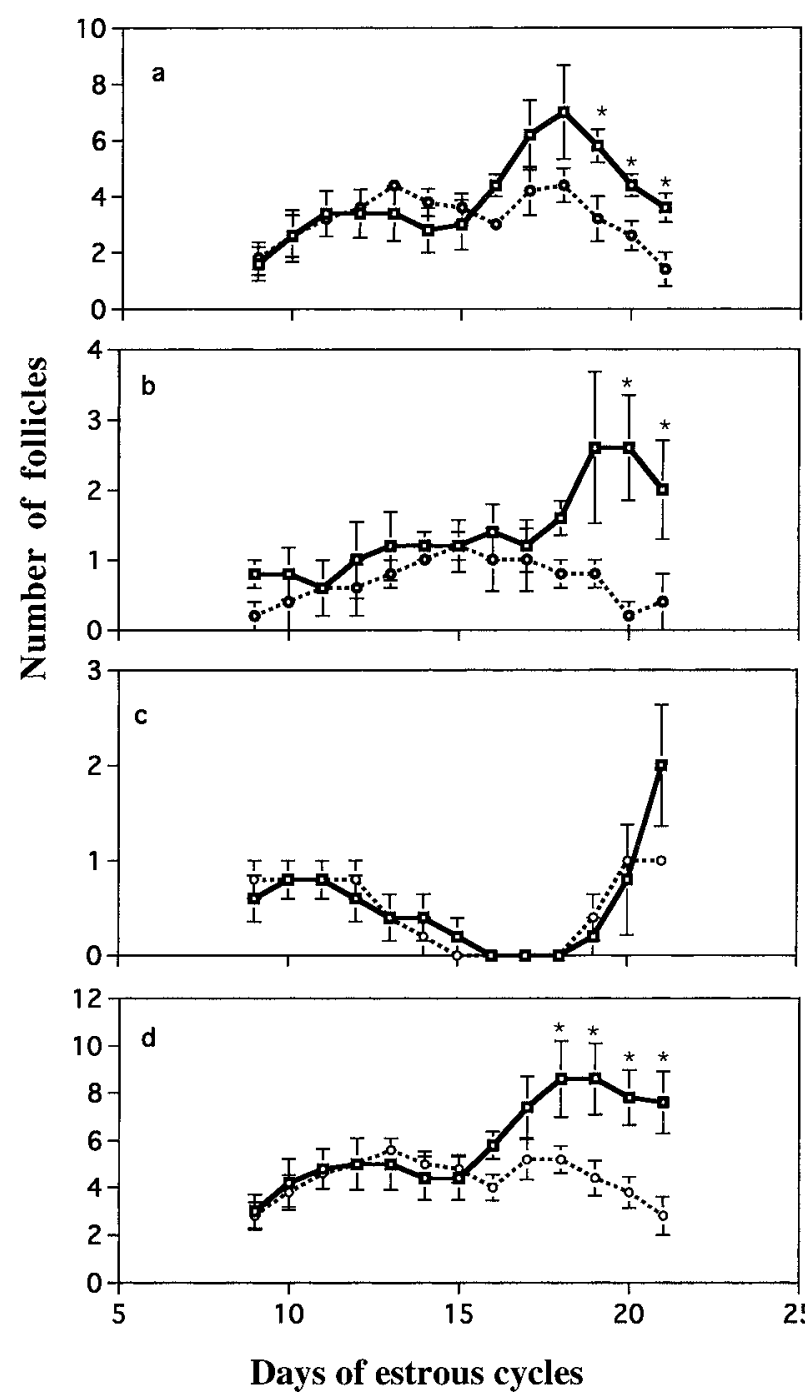

Fig. 2. Numbers of follicles in ovaries of immunized heifers after the second booster injection of placebo $(O)$ or inhibin vaccine $(\square)$ in the first year experiment. Note: (a) small follicles ( $\geq 4<7 \mathrm{~mm}$ in diameter), (b) medium follicles $(\geq 7<10 \mathrm{~mm}$ in diameter), (c) large follicles $(\geq 10$ $\mathrm{mm}$ in diameter), (d) total number of follicles. Values are shown as the means \pm SEM in five observations. * $\mathrm{P}<0.05$ compared with the value for the respective control (Student's t-test).

day period (days 9-19 of the estrus cycle) after the second booster injection than the values in the animals having a single ovulation, and this was consistent with a previous report [6]. Therefore, the results of the present study confirmed that active immunization against inhibin induced multiple ovulation mainly by attenuating of the suppressive effect of inhibin on FSH secretion in heifers.
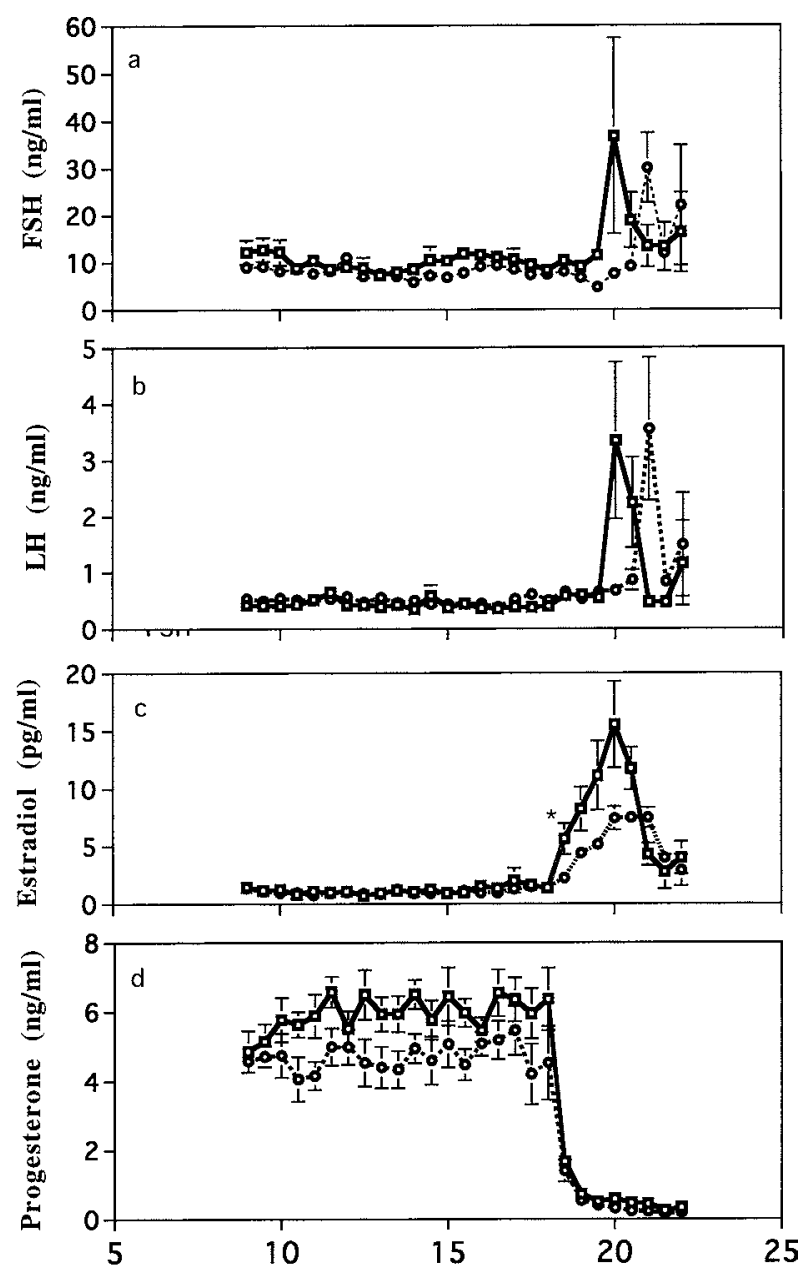

Days of estrous cycles

Fig. 3. Plasma concentrations of FSH (a), LH (b), estradiol (c) and progesterone (d) in immunized heifers after the second booster injection of placebo $(O)$ or inhibin vaccine ( $\square$ ) in the first year experiment. Values are shown as the means \pm SEM in five observations. * $\mathrm{P}<0.05$ compared with the value for the respective control (Student's t-test).

Consistent with previous findings [31], plasma concentrations of estradiol rose immediately after PG injection in all heifers. The peak level of plasma concentrations of estradiol in the inhibinimmunized group was about twice high as that in controls. This difference in the plasma concentration of estradiol is in agreement with the increase in the numbers of preovulatory follicles.

In summary, the present study clearly demonstrated that active immunization against the inhibin $\alpha$-subunit increased ovulation rates mainly 
by attenuating of the suppressive effect of inhibin on FSH secretion in heifers and indicated that reimmunization against inhibin was a good way to induce multiple ovulations in cattle.

\section{Acknowledgments}

We are grateful to Dr. D. J. Bolt, USDA, Beltsville, MD, U.S.A. for providing RIA materials for bovine FSH and LH; Dr. Y. Mori, The University of Tokyo, Japan for providing anti-ovine-LH (YM\#18); Dr. G.
D. Niswender, Animal Reproduction and Biotechnology Laboratory, Colorado State University, Fort Collins, CO, U.S.A. for providing antisera to estradiol-17 $\beta$ (GDN244) and progesterone (GDN337). This work was supported in part by a Grant-in-Aid (Bio Media Program) from the Ministry of Forestry and Fisheries, the Ito Foundation, the Japan Livestock Technology Association, and a Grant-in-Aid for COE Research (E-1) from the Ministry of Education, Science, Sports, and Culture, Japan.

\section{References}

1. Dietrich E, Hennies M, Holtz W, Voglmayr JK. Immunization of goats against recombinant human inhibin $\alpha$-subunit: Effects on inhibin binding, mating behavior, ovarian activity and embryo yield. Anim Reprod Sci 1995; 39: 119-128.

2. D'Alessandro A, Martemucci G, Iaffaldano $\mathbf{N}$. Active immunization with a synthetic fragment of pig inhibin $\alpha$-subunit increases ovulation rate and embryo production in superovulated ewes but season affects its efficiency. J Reprod Fertil 1999; 115: 185-191.

3. Shi F, Mochida K, Suzuki O, Matsuda J, Ogura A, Tsonis CG, Watanabe G, Suzuki AK, Taya K. Development of embryos in superovulated guinea pigs following active immunization against the inhibin $\alpha$-subunit. Endocrine J 2000; 47: 451-459.

4. Wrathall JM, McLeod BJ, Glencross RG, Knight PG. Effects of active immunization against a synthetic peptide sequence of the inhibin $\alpha$-subunit on plasma gonadotrophin concentrations, ovulation rate and lambing rate in ewes. J Reprod Fertil 1992; 95: 175-182.

5. Takedomi T, Kaneko H, Aoyagi Y, Konishi K, Kishi H, Watanabe G, Taya K. Effects of passive immunization against inhibin on ovulation rate and embryo recovery in Holstein heifers. Theriogenology 1997; 47: 1507-1518.

6. Kishi H, Okada T, Otsuka M, Watanabe G, Taya K. Induction of superovulation by immunoneutralization of endogenous inhibin through the increase in the secretion of folliclestimulating hormone in the cyclic golden hamster. $J$ Endocr 1996; 151: 65-75.

7. Nambo $Y$, Kaneko $H$, Nagata $S$, Oikawa $M$, Yoshihara T, Nagamine N, Watanabe G, Taya K. Effect of passive immunization against inhibin on FSH secretion, folliculogenesis and ovulation rate during the follicular phase of the estrous cycle in mares. Theriogenology 1998; 50: 545-557.
8. Wang H, Herath CB, Xia G, Watanabe G, Taya K. Superovulation, fertilization and in vitro embryo development in the mice after administration of an inhibin-neutralizing antiserum. Reproduction 2001; 122: 809-816.

9. Glencross RG, Bleach ECL, McLeod BJ, Beard AJ, Knight PG. Effect of active immunization of heifers against inhibin on plasma FSH concentrations, ovarian follicular development and ovulation. J Endocrinol 1992; 134: 11-18.

10. Hillard MA, Wilkins JF, Cummins LJ, Bindon BM, Tonis CG, Findlay JK, O'Shea T. Immunological manipulation of ovulation rate for twinning incattle. J Reprod Fertil Suppl 1995; 49: 351-364.

11. Morris DG, McDermott MG, Diskin MG, Morrison CA, Swift PJ, Sreenan JM. Effect of immunization against synthetic peptide sequences of bovine inhibin $\alpha$-subunit on ovulation rate and twin-calving rate in heifers. J Reprod Fertil 1993; 97: 255-261.

12. O'Shea T, Hillard MA, Anderson ST, Bindon BM, Findlay JK, Tonis CG, Wilkins JF. Inhibin immunization for increasing ovulation rate and superovulation. Theriogenology 1994; 41: 3-17.

13. Scanlon AR, Sunderland SJ, Martin TL, Goulding D, O'Callaghan D, Williams DH, Headon DR, Boland MP, Ireland JJ, Roche JF. Active immunization of heifers against synthetic fragment of bovine inhibin. J Reprod Fertil 1994; 97: 213-222.

14. Akagi S, Kaneko H, Nakanishi Y, Takedomi T, Watanabe G, Taya K. Ovarian response and FSH profile in cows following injection of various doses of inhibin antiserum. I Vet Med Sci 1997; 59: 1129_ 1135.

15. Adams GP, Matteri RL, Kastelic JP, Ko JCH, Ginther OJ. Association between surges of folliclestimulating hormone and the emergence of follicular waves in heifers. J Reprod Fertil 1992; 94: 177-188. 
16. Kaneko H, Kishi H, Taya K, Watanabe G, Sasamoto S, Hasegawa Y. Changes in plasma concentrations of immunoreactive inhibin estradiol and FSH associated with follicular waves during the estrous cycle of the cow. J Reprod Dev 1995; 41: 311320.

17. Forage RG, Brown RW, Oliver KJ, Attache BT, Devine PL, Hudson GC, Goss WH, Bertram KC, Tolstoshev P, Robertson DM, Doughton B, Burger HG, Findlay JK. Immunisation against an inhibin subunit produced by recombinant DNA techniques results in increased ovulation rate in sheep. J Endocrinol 1987; 114: R1-R4.

18. Kaneko H, Terada T, Taya K, Watanabe G, Sasamoto S, Hasegawa Y, Igarashi M. Ovarian follicular dynamics and concentrations of estradiol$17 \beta$, progesterone, luteinizing hormone and follicle stimulating hormone during the periovulatory phase of the oestrous cycle in the cow. Reprod Fertil Dev 1991; 3: 529-535.

19. Bolt DJ, Rollins R. Development and application of a radioimmunoassay for bovine follicle-stimulating hormone. J Anim Sci 1983; 56: 146-154.

20. Echternkamp SE, Bolt DJ, Hawk HW. Ovarian and pituitary hormones in blood of progestogen-treated ewes. J Anim Sci 1976; 42: 893-900.

21. Taya K, Watanabe G, Sasamoto S. Radioimmunoassay for progesterone, testosterone and estradiol-17 $\beta$ using ${ }^{125}$ I-iodohistamine radioligands. Jpn J Anim Reprod 1985; 31: 186-197.

22. Nagata S, Kondou M, Kaneko H, Araki K, Nambo Y, Oikawa M, Watanabe G, Taya K. A simple defatting method using a partition method of acetonitorile and $\mathrm{n}$-hexan for radioimmunoassay of low blood levels of estradiol-17 $\beta$. J Reprod Dev 1996; 42: j43-j49.

23. Kaneko H, Nakanisi $Y$, Taya $K$, Kishi H, Watanabe G, Sasamoto S, Hasegawa Y. Evidence that inhibin is an important factor in the regulation of $\mathrm{FSH}$ secretion during the mid-luteal phase in cows. $J$
Endocrinol 1993; 136: 35-41.

24. Glantz SA, Slinker BK. Repeated measures. In: Primer of Applied Regression and Analysis of Variance, McGraw-Hill, New York, 1990: 381-463.

25. SAS. SAS/STAT User's Guide, release 6.03 ed. 1988. Statistical Analysis System Institute, Inc, Cary, NC.

26. Bleach ECL, Muttukrishna S, Cunningham FJ, Knight PG, Glencross RG. Effect of inhibin immunization using different synthetic peptide fragments of the bovine $\alpha$-subunit on plasma antiinhibin titres, plasma FSH concentrations and the incidence of multiple ovulation in heifers. Anim Reprod Sci 1996; 41: 1-12.

27. Glencross RG, Bleach ECL, Wood SC, Knight PG. Active immunization of heifers against inhibin: effects on plasma concentrations of gonadotrophins, steroids and ovarian follicular dynamics during prostaglandin-synchonized cycles. J Reprod Fertil 1994; 100: 599-605.

28. Henderson KM, McNeilly AS, Swanston IA. Gonadotrophin and steroid concentrations in bovine follicular fluid and their relationship to follicle size. J Reprod Fertil 1982; 65: 467-473.

29. Morris DG, Grealy M, Sreenan JM. Effect of immunization against synthetic peptide sequences of bovine inhibin $\alpha$-subunit on gonadotrophin concentrations in heifers. Anim Reprod Sci 1995; 38: 63-71.

30. Morris DG, McDermott MG, Grealy M, Diskin MG, Morrison CA, Swift PJ, Sreenan JM. Effect of immunization against synthetic peptide sequences of the $\alpha$-subunit of bovine inhibin on ovulation rate, gonadotrophin concentrations in heifers. J Reprod Fertil 1995b; 103: 285-291.

31. Turzillo AM, Fortune JE. Suppression of the secondary FSH surge with bovine follicular fluid is associated with delayed ovarian follicular development in heifers. J Reprod Fertil 1990; 89: 643653. 